Conrad and Masculinity 
Also by Andrew Michael Roberts

CONRAD AND GENDER

JOSEPH CONRAD

THE NOVEL 


\section{Conrad and Masculinity}

Andrew Michael Roberts

Senior Lecturer in English

University of Dundee 
First published in Great Britain 2000 by

MACMILLAN PRESS LTD

Houndmills, Basingstoke, Hampshire RG21 6XS and London

Companies and representatives throughout the world

A catalogue record for this book is available from the British Library.

ISBN 978-1-349-39816-4 ISBN 978-0-230-28897-3 (eBook)

DOI $10.1057 / 9780230288973$

First published in the United States of America 2000 by

ST. MARTIN'S PRESS, INC.,

Scholarly and Reference Division,

175 Fifth Avenue, New York, N.Y. 10010

ISBN 978-0-312-22782-1

Library of Congress Cataloging-in-Publication Data

Roberts, Andrew Michael.

Conrad and masculinity / Andrew Michael Roberts.

p. $\mathrm{cm}$.

Includes bibliographical references (p. ) and index.

ISBN 978-0-312-22782-1 (cloth)

1. Conrad, Joseph, 1857-1924-Characters-Men. 2. Psychological

fiction, English-History and criticism. 3. Adventure stories,

English-History and criticism. 4. Conrad, Joseph, 1857-1924-

-Knowledge-Psychology. 5. Masculinity in literature. 6. Men in

literature. I. Title.

PR6005.O4Z7879 1999

$823^{\prime} .912-\mathrm{dc} 21$

99-42654

CIP

(C) Andrew Michael Roberts 2000

Softcover reprint of the hardcover 1st edition 2000 978-0-333-66285-4

All rights reserved. No reproduction, copy or transmission of this publication may be made without written permission.

No paragraph of this publication may be reproduced, copied or transmitted save with written permission or in accordance with the provisions of the Copyright, Designs and Patents Act 1988, or under the terms of any licence permitting limited copying issued by the Copyright Licensing Agency, 90 Tottenham Court Road, London W1P 0LP.

Any person who does any unauthorised act in relation to this publication may be liable to criminal prosecution and civil claims for damages.

The author has asserted his right to be identified as the author of this work in accordance with the Copyright, Designs and Patents Act 1988.

This book is printed on paper suitable for recycling and made from fully managed and sustained forest sources.

$\begin{array}{llllllllll}10 & 9 & 8 & 7 & 6 & 5 & 4 & 3 & 2 & 1\end{array}$

$\begin{array}{llllllllll}09 & 08 & 07 & 06 & 05 & 04 & 03 & 02 & 01 & 00\end{array}$ 
To the memory of my mother, Judith Roberts 
This page intentionally left blank 


\section{Contents}

Acknowledgements viii

Abbreviations and Note on Texts ix

Introduction 1

1 Masculinity, 'Race' and Empire: Almayer's Folly, An Outcast of the Islands 13

2 Imperialism and Male Bonds: 'Karain', The Nigger of the 'Narcissus', Lord Jim 44

3 Masculinity and the Body: Typhoon, The Secret Agent 66

4 Gender and the Disciplined Body: Nostromo 94

5 Epistemology, Modernity and Masculinity: 'Heart of Darkness' 118

6 Masculinity, 'Woman' and Truth: The Secret Agent, Under Western Eyes, Chance 137

7 Vision, Power and Homosocial Exchange: The Arrow of Gold 163

8 Vision and the Economies of Empire and Masculinity: $\begin{array}{ll}\text { Victory } & 186\end{array}$

Notes 211

Bibliography 233

Index 243 


\section{Acknowledgements}

I would like to thank Jeremy Hawthorn for his knowledgeable and insightful comments on drafts of this book; Robert Hampson for learned advice on matters Conradian and Hugh Epstein for numerous little, nameless (but not unremembered) acts of kindness. Many fellow Conradians have provided inspiration and food for thought over the period when this book was developing, among whom I would particularly like to mention Padmini Mongia and Jakob Lothe. Special thanks to Jim Stewart for his work on the index. Some of the material in this book has appeared, in earlier form, in The Conradian (Journal of the Joseph Conrad Society, UK), L'Époque Conradienne (Journal of the Sociéte Conradienne Française), Kunapipi (Special Edition, also appearing as Imperialism and Gender, ed. C.E. Gittings, Dangaroo Press, 1996) and Joseph Conrad: Critical Assessments, ed. Keith Carabine (Helm, 1992). I am grateful to the editors or publishers of these works for permission (where appropriate) to reprint material. 


\section{Abbreviations and Note on Texts}

\section{Conrad's works}

\begin{tabular}{|c|c|}
\hline$A F$ & Almayer's Folly: A Story of an Eastern River (1895). \\
\hline$A G$ & $\begin{array}{l}\text { The Arrow of Gold: A Story between Two Notes (1918-20; } \\
\text { 1919). }\end{array}$ \\
\hline C & Chance: A Tale in Two Parts (1912; 1913). \\
\hline$C L$ & $\begin{array}{l}\text { The Collected Letters of Joseph Conrad, eds Frederick R. Karl } \\
\text { and Laurence Davies, } 5 \text { vols (Cambridge: Cambridge } \\
\text { University Press, 1983-96). }\end{array}$ \\
\hline $\mathrm{OD}$ & $\begin{array}{l}\text { 'Heart of Darkness', in Youth, a Narrative, and Two Other } \\
\text { Stories }(1899 ; 1902) .\end{array}$ \\
\hline $\mathrm{K}$ & 'Karain: A Memory', in Tales of Unrest (1897; 1898). \\
\hline$L E$ & Last Essays (1926). \\
\hline$L J$ & Lord Jim: A Tale (1899-1900; 1900). \\
\hline$N$ & Nostromo: A Tale of the Seaboard (1904). \\
\hline NN & The Nigger of the 'Narcissus': A Tale of the Sea $(1897 ; 1898)$. \\
\hline$O I$ & An Outcast of the Islands (1896). \\
\hline$R$ & The Rescue: A Romance of the Shallows (1919; 1920). \\
\hline$S A$ & The Secret Agent: A Simple Tale (1906-7; 1907). \\
\hline$S L$ & The Shadow-Line: A Confession (1916-17; 1917). \\
\hline & 'Typhoon', in Typhoon and Other Stories (1902). \\
\hline & Under Western Eyes: A Novel (1910-11; 1911). \\
\hline & Victory: An Island Tale (1915). \\
\hline
\end{tabular}

\section{Note on texts and quotations}

Where two dates are given above, the first indicates serial publication. The second (or, in some cases, only) date refers to the first appearance in book form of the particular text. The titles of collections are those of the Dent's Collected Edition, and all page references to Conrad's works are to this edition (London: J.M. Dent \& Sons, 1923-8) and are given in the text. The plates of this edition are photographically reproduced, with some minor corrections, in the World's Classics (Oxford University Press) editions of Conrad's texts, which therefore in most cases share the same page numbers for the main text (though the roman numerals of the Author's Notes are not the same). Minor 
corrections made in the World's Classics editions have been silently incorporated in quotations.

The Dent edition, long regarded as standard, is gradually being superseded by the new Cambridge University Press edition, which establishes more accurate texts based on research in the original documents. However, at the time of writing, only Almayer's Folly and The Secret Agent have been published. I have checked all quotations against the Cambridge editions of these two works, and noted any amendments which significantly alter the sense of the quoted passage.

Conrad quite frequently made use of ellipses in his fiction. In quotations from Conrad's work, I have followed the convention established by other critics of Conrad, in which spaced dots indicate an ellipsis in the original text, while three unspaced dots indicate my own ellipsis.

\section{Other texts}

AT Andrea White, Joseph Conrad and the Adventure Tradition: Constructing and Deconstructing the Imperial Subject (Cambridge: Cambridge University Press, 1993).

BM Eve Kosofsky Sedgwick, Between Men: English Literature and Male Homosocial Desire (New York: Columbia University Press, 1985).

CG Andrew Michael Roberts (ed.), Conrad and Gender (Amsterdam and Atlanta, GA: Rodopi, 1993).

DD René Girard, Deceit, Desire and the Novel: Self and Other in Literary Structure, trans. Yvonne Freccero (Baltimore, MD and London: Johns Hopkins University Press, 1965).

EC Eve Kosofsky Sedgwick, Epistemology of the Closet (1990; Hemel Hempstead: Harvester Wheatsheaf, 1991).

EI Nina Pelikan Straus, 'The Exclusion of the Intended from Secret Sharing in Conrad's "Heart of Darkness"', Novel, 20 (1987), 123-37.

EM Chris Bongie, Exotic Memories: Literature, Colonialism and the Fin de Siècle (Stanford, CA: Stanford University Press, 1991).

FP Karen Klein, 'The Feminist Predicament in Conrad's Nostromo', in Brandeis Essays in Literature, ed. John Hazel Smith (Waltham, MA: Dept of English and American Literature, Brandeis University, 1983), pp. 101-16.

FS Mark Wollaeger, Joseph Conrad and the Fictions of Skepticism (Stanford, CA: Stanford University Press, 1990).

MS Kaja Silverman, Male Subjectivity at the Margins (New York and London: Routledge, 1992) 
NT Jeremy Hawthorn, Joseph Conrad: Narrative Technique and Ideological Commitment (London: Edward Arnold, 1990).

PPT Peter Stallybrass and Allon White, The Politics and Poetics of Transgression (London: Methuen, 1986).

PU Fredric Jameson, The Political Unconscious: Narrative as a Socially Symbolic Act (1981; London: Routledge, 1989).

$S \quad$ Luce Irigaray, Speculum of the Other Woman, trans. Gillian C. Gill (Ithaca, NY: Cornell University Press, 1985).

SD Steve Neale, 'Sexual Difference in Cinema - Issues of Fantasy, Narrative and the Look', Oxford Literary Review, 8.1/8.2 (1986), 123-32.

TS Luce Irigaray, This Sex Which is Not One, trans. Catherine Porter (Ithaca, NY: Cornell University Press, 1985).

TW Gayle Rubin, 'The Traffic in Women: Notes on the "Political Economy" of Sex', in Toward an Anthropology of Women, ed. Rayna R. Reiter (New York and London: Monthly Review Press, 1975), pp. 157-210. 